\title{
UM ESTUDO DE APLICAÇÃO DA SÍSMICA DE REFLEXÃO RASA COM ONDAS P E ONDAS S EM ÁREA URBANA: AQUISIÇÃO E PROCESSAMENTO
}

\author{
Oleg Bokhonok \\ Orientador: Dr. Renato Luiz Prado (IAG-USP) \\ 92 p. - Dissertação (Mestrado) - Defesa 13.05.2005
}

RESUMO. Este trabalho avalia a potencialidade do uso da sísmica rasa de reflexão na investigação geológica-geotécnica em ambientes urbanos ruidosos e com superfície pavimentada. Foi efetuado um estudo abordando diversos aspectos relacionados à aquisição e processamento dos dados sísmicos, e particularmente sobre os problemas relacionados ao acoplamento de sensores nos terrenos pavimentados. Avalia também o uso da sísmica de reflexão com ondas $S$ visando ao aumento da resolução vertical, bem como sua integração com os dados obtidos com a sísmica com ondas $P$. Os ensaios de campo foram realizados em terrenos da Bacia Sedimentar de São Paulo, na área urbana da cidade de São Paulo. Verificou-se que os geofones de freqüência natural de $100 \mathrm{~Hz}$ e fonte de impacto, tipo marreta, tiveram os melhores desempenhos na área urbana estudada, mesmo sobre o pavimento asfáltico, uma vez que testes de laboratório e de campo demonstraram que os geofones podem ser acoplados através da argila mantendo suas características de resposta. Testes de laboratório indicaram que a resposta do geofone depende do tipo de argilomineral empregado. Testes de análise de ruído mostraram que o emprego da sísmica de reflexão com ondas SH, embora operacionalmente mais complicado, traz informações complementares às obtidas com ondas $P$. A interpretação da seção CMP apresentou um grande potencial no mapeamento das estruturas de maneira contínua, podendo interpolar as informações dos furos de sondagem. A informação obtida pela seção sísmica final revelou diferentes estratos dos sedimentos da Bacia de São Paulo e estruturas do embasamento. Os resultados alcançados caracterizaram a sísmica rasa de reflexão como uma ferramenta flexível que pode adaptar-se aos objetivos do problema proposto, desde que definidos parâmetros de aquisição adequados, e realizado um processamento criterioso.

ABSTRACT. This work evaluates the potentiality of the shallow seismic reflection for the geological and geotechnical investigation in noisy urban environments with paved surface. The study approached several aspects related to the acquisition and processing of the seismic data, and particularly to the problems of coupling of sensors. It also evaluates the use of $S$-waves seismic reflection method aiming to enhance the geological resolution, as well its potential to get additional information regarding the $P$-waves acquisition. The field tests were made on the Sedimentary Basin of São Paulo, in the urban area of the city of São Paulo. It was verified that the use of $100 \mathrm{~Hz}$ geophones and the sledge hammer were more suitables, even on the paved terrains. The field and laboratory tests demonstrated that the geophones can be coupled with clay keeping their standard response. The laboratory tests also indicated that the response of the geophone depends on the kind of clay employed. Walkaway noise tests shown that the use of seismic reflection with SH-waves, although operationally more complicated, brings additional information, which complements those obtained with $P$-waves. The interpretation of CMP section, when interpolated with well information, presented a great potential in mapping the geological structures with great details and continuity. The information obtained with the final seismic section revealed different strata of the sediments of the Basin of São Paulo and structures of the bedrock. The results had characterized the shallow seismic reflection method as a flexible tool that can be adapted to the objectives of the proposed problem, by definition of adequate parameters of the acquisition and through a perceptive processing. 